\title{
Genetic diversity in peripheral and central populations of the Cantabrian endemism Genista legionensis (Pau) M. Laínz (Fabaceae)
}

\author{
Eduardo Cires ${ }^{1,2 *}$, René Pérez ${ }^{1}$, Álvaro Bueno ${ }^{3}$ \& José Antonio Fernández Prieto ${ }^{1}$ \\ 'Departamento de Biología de Organismos y Sistemas, Universidad de Oviedo, Catedrático Rodrigo Uría s/n, E-33071 Oviedo, Spain \\ ${ }^{2}$ Department of Biology, Research Group Spermatophytes, Ghent University, K.L. Ledeganckstraat 35, 9000 Ghent, Belgium \\ 3jardín Botánico Atlántico / INDUROT Universidad de Oviedo, Avenida del Jardín Botánico 2230, E-33394 Gijón, Spain \\ cireseduardo@gmail.com
}

\begin{abstract}
Cires, E., Pérez, R., Bueno, A. \& Fernández Prieto, J.A. 2013. Genetic diversity in peripheral and central populations of the Cantabrian endemism Genista legionensis (Pau) M. Laínz (Fabaceae). Anales Jard. Bot. Madrid 70(1): 91-96.

The impact of habitat fragmentation and isolation on the genetic diversity of populations has attracted much attention in studies of plant conservation. The central-peripheral population hypothesis predicts that peripheral populations have reduced genetic variability, so it is often assumed that they deserve higher conservation priority over central populations. In this work, using amplified fragment length polymorphism (AFLP), we studied the genetic diversity of central and peripheral populations of the Cantabrian endemism Genista legionensis (Fabaceae). At the species level, percentage of polymorphic bands, Nei heterozygosity and Shannon information index were $\mathrm{PPB}=89.21 \%, H_{\mathrm{E}}=0.246$ and $I=0.377$, respectively. The study revealed that peripheral populations were smaller in number, with lower levels of genetic diversity compared to the central populations. Furthermore, analysis of molecular variance (AMOVA) indicated that most of the variability was partitioned among populations, also supported by principal coordinates analysis. This study indicates that the decrease in diversity from central to peripheral populations could be explained as a result of edge effect and fragmentation through the enhanced inbreeding and genetic drift, and thus supported the view that habitat fragmentation and related edge effect reduce the population genetic diversity. However, the presence of discriminating fragments in the peripheral populations suggests their conservation in order to preserve the genetic diversity in the Cantabrian endemism $\mathrm{G}$. legionensis.
\end{abstract}

Keywords: AFLP, central populations, edge effect, endangered species, endemism, genetic diversity, peripheral populations, plant conservation.

\section{INTRODUCTION}

Genista L. is a genus of spiny and non-spiny shrubs centred in the Mediterranean region, which includes over 90 species divided into three subgenera and ten sections (Gibbs, 1996). The genus is also represented throughout most of western and central Europe, extending to the southeast of the former USSR, and Turkey, Syria and North Africa (De Castro \& al., 2002; Pardo \& al., 2004). In the Iberian Peninsula, the genus is widespread in the Mediterranean part of the country and represented by thirty-nine species in the Iberian flora (see Talavera, 1999). Additionally, it is prevalent at the transition zones between the Mediterranean and Euroatlantic bioclimatic regions. This is the case of Genista legionensis ( $\mathrm{Pau}) \mathrm{M}$. Laínz, an endemic plant that grows on limestone from near sea level to altitudes of $2200 \mathrm{~m}$. Its distribution comprises the central area of the Cantabrian Range (Asturias, Cantabria,

\section{Resumen}

Cires, E., Pérez, R., Bueno, A. \& Fernández Prieto, J.A. 2013. Diversidad genética en poblaciones periféricas y centrales del endemismo cantábrico Genista legionensis (Pau) M. Laínz (Fabaceae). Anales Jard. Bot. Madrid 70(1): $91-96$ (en inglés).

El impacto de la fragmentación del hábitat y el aislamiento sobre la diversidad genética de las poblaciones, han despertado mucha atención en estudios de conservación de plantas. La hipótesis de la población centro-periferia predice que las poblaciones periféricas reducen la variabilidad genética, por lo que a menudo se asume que merecen una mayor prioridad de conservación respecto a las poblaciones centrales. En este trabajo, hemos empleado los polimorfismos en longitud de fragmentos amplificados (AFLP), para estudiar la diversidad genética de las poblaciones centrales y periféricas del endemismo cantábrico Genista legionensis (Fabaceae). A nivel de especie, el porcentaje de bandas polimórficas, la heterocigosidad de Nei y el índice de Shannon fueron PPB $=89,21 \%, H_{\mathrm{E}}=$ 0,246 y $I=0,377$, respectivamente. El estudio reveló que las poblaciones periféricas fueron menores en número, con niveles más bajos de diversidad genética si las comparamos con las poblaciones centrales. Además, el análisis molecular de la varianza (AMOVA) indicó que la mayor parte de la variabilidad tuvo lugar entre las poblaciones, también apoyado por el análisis de coordenadas principales. Este estudio indica que la disminución de la diversidad desde el centro hasta las poblaciones periféricas, puede deberse a un efecto de borde y fragmentación acompañado de endogamia y deriva génica, y por ello apoya la idea de que la fragmentación del hábitat y el efecto borde están relacionados con una reducción de la diversidad genética poblacional. Sin embargo, la presencia de fragmentos discriminantes en las poblaciones periféricas sugiere su conservación a fin de preservar la diversidad genética del endemismo Cantábrico $G$. legionensis.

Palabras clave: AFLP, poblaciones centrales, efecto borde, especies en peligro, endemismo, diversidad genética, poblaciones periféricas, conservación de plantas.

León and Palencia), with some isolated locations out of this core (south of Palencia, País Vasco, Cantabria and western Asturias). In regard to its protection status, G. legionensis does not appear in the Royal Decree 139/2011 (Listado de Especies Silvestres en Régimen de Protección Especial y del Catálogo Español de Especies Amenazadas) neither in the Red List of Spanish Vascular Flora (VV.AA., 2000; Bañares \& al., 2004; Moreno, 2008). Llamas \& al. (2007) analyzed its frequency in the catalogue of threatened vascular plants of Castilla y León and suggested the criteria of "frequent endemism”. In Asturias, Barreno \& al. (1985) and Gómez-Campo (1987) included G. legionensis under the category of "not threatened", and Fernández Prieto \& al. (2007) suggested its exclusion from the catalogue of threatened vascular plants of Asturias. On the contrary, in the País Vasco where only one locality has been reported (Monte Lucero, Vizcaya), G. legio-

\footnotetext{
* Corresponding author.
} 
Table 1. Sampling localities of Genista legionensis used in this study.

\begin{tabular}{|c|c|c|c|c|c|}
\hline Code & Population & Locality & Coordinates & $\begin{array}{l}\text { Sample } \\
\text { size }\end{array}$ & $\begin{array}{l}\text { Voucher } \\
\text { specimens }\end{array}$ \\
\hline GA & Peripheral & $\begin{array}{l}\text { Gamoniteiro, Quirós (Asturias, Spain); } \\
1534 \mathrm{~m} ; A B \text { \& JAFP }\end{array}$ & $\begin{array}{l}43^{\circ} 11^{\prime} 42.8^{\prime \prime} \mathrm{N} \\
5^{\circ} 55^{\prime} 31.0^{\prime \prime} \mathrm{W}\end{array}$ & 13 & JBAG: 04753 \\
\hline CA & Central & $\begin{array}{l}\text { Between Carreño and Ortiguero, Cabrales } \\
\text { (Asturias, Spain); } 373 \mathrm{~m} ; A B \text { \& JAFP }\end{array}$ & $\begin{array}{l}43^{\circ} 19^{\prime} 5.0^{\prime \prime} \mathrm{N} \\
4^{\circ} 53^{\prime} 27.8^{\prime \prime} \mathrm{W}\end{array}$ & 13 & JBAG: 04754 \\
\hline$M L$ & Peripheral & $\begin{array}{l}\text { Monte Lucero, Muskiz (Vizcaya, Spain); } \\
173 \mathrm{~m} ; A B, A P, E C \& J A F P\end{array}$ & $\begin{array}{l}43^{\circ} 20^{\prime} 58.8^{\prime \prime} \mathrm{N} \\
3^{\circ} 5^{\prime} 13.1^{\prime \prime} \mathrm{W}\end{array}$ & 22 & BIO: 5770 \\
\hline
\end{tabular}

Collector abbreviations: AB, A. Bueno; AP, A. Prieto; EC, E. Cires; JAFP, J.A. Fernández Prieto.

nensis is listed as a species "at risk of extinction" (see B.O.P.V., 1998). Therefore, as most Cantabrian endemic species occurring on habitats exposed to risk of fragmentation, this taxon has interest in the field of conservation biology. The effect of such fragmentation and isolation on the population genetic diversity of this Cantabrian endemism is still unknown.

Understanding the partitioning of genetic variance in peripheral and central populations may shed more light on the effects of genetic drift and gene flow on population genetic structure and, thereby, improve attempts to conserve genetic diversity. There are two opposite scenarios about the genetic diversities in central and peripheral populations. The first view is that, because the peripheral population is small, isolated and at the edge of suitable habitat (Lawton, 1993; Lesica \& Allendorf, 1995), it suffers inbreeding and genetic drift; so the genetic diversity of these peripheral isolated populations will be reduced. Another view is that the peripheral population experiences high and various natural selection (Lesica \& Allendorf, 1992, 1995); then strong selective pressure may promote differentiation of those populations subjected to selection, and these populations would be the sources for producing new species and should be well preserved as a priority (Höglund, 2009).
In this work, using Amplified Fragment Length Polymorphism (AFLP) (Vos \& al., 1995), we studied the genetic diversity of central and peripheral populations of Genista legionensis. In particular, we addressed the following questions: (1) what is the level of genetic diversity in populations of Genista legionensis? (2) how is the genetic diversity distributed within and between populations?, and finally (3) are the peripheral populations genetically depauperate compared with central populations? As a result of evaluating the genetic status in this Cantabrian endemism, conservation and management strategies are proposed.

\section{MATERIAL AND METHODS}

\section{Sampling design and DNA isolation}

Genista legionensis specimens were collected in three localities from the Cantabrian Range (see Table 1, Fig. 1A). In the central population "Cabrales" (CA), 13 individuals were randomly collected, with a distance of at least $5 \mathrm{~m}$ each other. In the case of peripheral populations, and considering the specific structure of each population, two sampling strategies were carried out: the first one in the population of Monte Lucero (ML), with 22 individuals structured in three subnuclei (Fig. 1B; information provided by Amador Prieto, De-

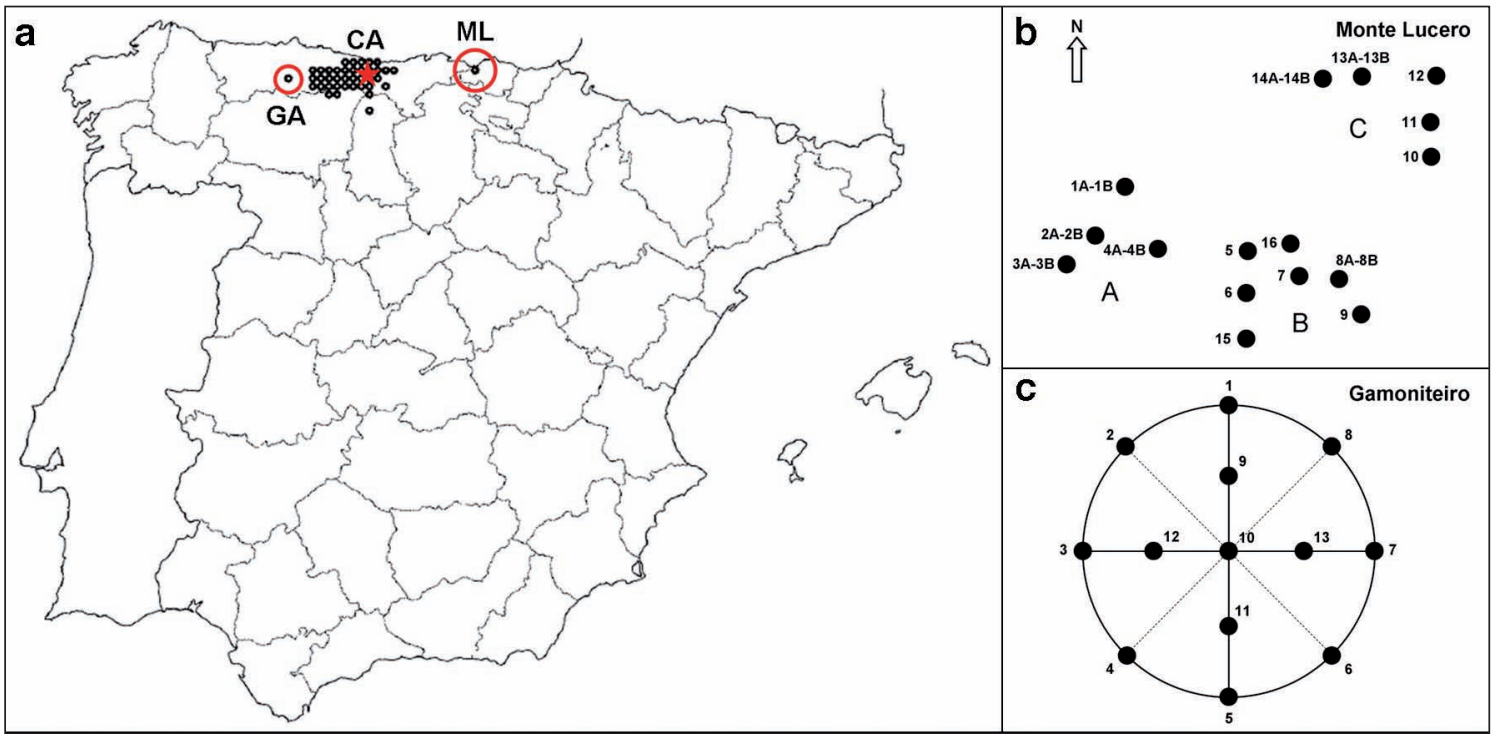

Fig. 1. Distribution map of the examined specimens of Genista legionensis (a), and different sampling strategies for the peripheral populations Monte Lucero (b) and Gamoniteiro (c). Populations are coded as in Table 1. Distribution map modified from Vera de la Puente \& al. (2002). CA, Cabrales; GA, Gamoniteiro; ML, Monte Lucero. 
partamento de Medio Ambiente, Planificación Territorial, Agricultura y Pesca, Gobierno Vasco). In this case all individuals were sampled with the exception of number 6 , which was not found. The second sampling strategy was conducted in the population of Gamoniteiro (GA). This peripheral population is a continuous stand of $100 \mathrm{~m}^{2}$, so 13 individuals, distributed along two perpendicular diameters and the periphery were targeted for sampling (Fig. 1C). All the collected specimens were dried in silica gel and stored prior to DNA isolation. DNA isolation was carried out using the DNeasy Plant Minikit (Qiagen) following the manufacturer's instructions. In addition, voucher herbarium specimens were collected and kept in the Herbaria of the Atlantic Botanical Garden (JBAG) and University of the Basque Country (BIO).

\section{AFLP analysis}

AFLP analysis followed the protocol from Vos \& al. (1995) with minor modifications. DNA was isolated from silica geldried material collected in the field, digested with restriction enzymes EcoRI and MseI (New England Biolabs) for $2 \mathrm{~h}$ at 37 ${ }^{\circ} \mathrm{C}$ and simultaneously ligated to double-stranded EcoRI and MseI adapters (Applied Biosystems). Preselective amplifications were performed using primers with one base pair extension. In a second selective amplification, the number of fragments was further reduced by primers with three base pair extension. For this second amplification, four primer combinations (Applied Biosystems) were used (Table 2). For a more detailed explanation of the AFLP technique and quality parameters applied, see Cires \& al. (2011). Selective amplification products were sent to the Sequencing Services of the University of Oviedo for fragment analysis: samples were run on an automated DNA sequencer (ABI PRISM® 3100, Applied Biosystems) with an internal size standard GeneScan 500 (ROX ${ }^{\mathrm{TM}}$, Applied Biosystems). Raw AFLP data were collected and sized using the Genemapper 4.0 software (Applied Biosystems).

\section{Data analysis}

The presence or absence of each band was recorded in a binary data matrix for each individual, assigning a value of 1 or 0 depending on band presence or absence, respectively. The binary data matrix obtained was used to calculate the following parameters assuming Hardy-Weinberg equilibrium: observed number of bands (NB), number of polymorphic bands $(\mathrm{NPB})$, percentage of polymorphic bands $(\mathrm{PPB})$, mean ob-
Table 2. Primer combinations used for AFLP amplification and summary of amplified bands.

\begin{tabular}{llcc}
\hline Primer pairs & NB & NPB & PPB (\%) \\
\hline EcoRI-ACG / Msel-CAT & 183 & 164 & 89.61 \\
EcoRI-ACG / Msel-CTT & 256 & 219 & 85.54 \\
EcoRI-ACT / Msel-CAT & 241 & 226 & 93.77 \\
EcoRI-ACT / Msel-CTT & 228 & 201 & 88.15 \\
Total & 908 & 810 & \\
\hline
\end{tabular}

NB, number of scorable bands; NPB, number of polymorphic bands; PPB, percentage of polymorphic bands.

served number of alleles $\left(A_{\circ}\right)$, mean effective number of alleles $\left(A_{\mathrm{E}}\right)$, observed heterozygosity $\left(H_{\mathrm{E}}\right)$, and lastly, Shannon diversity index $(I)$. The numbers of distinguishing markers were quantified for the different populations using the following criteria: "discriminating" fragments - present in all analysed samples of a given population and absent elsewhere, and "private" fragments - restricted to a given population but not present in all of its samples. The hierarchical AFLP frequency distribution was described using the analysis of molecular variance (AMOVA). Components of variance partitioned within populations and among populations were estimated from a Euclidean distance matrix using GenAlEx 6.4 (Peakall \& Smouse, 2006).

A principal coordinate analysis ( $\mathrm{PCoA}$ ) was performed on the Jaccard similarity matrix using Past 1.89 (Hammer \& al., 2001) to visualise the genetic relationships among all individual AFLP phenotypes. In addition, a NeighborNet was constructed based on a matrix of $\mathrm{p}$-distances, using the program SplitsTree 4.12 (Huson \& Bryant, 2006) to examine genetic structure and reticulation in the AFLP data. Bootstrap support for internal splits was calculated with 2,000 replicates. Fit values ranging from 0 to $100 \%$ indicate how well the graph represents the information contained in the data.

\section{RESULTS}

The four selected primers generated a total of 908 bands for the 48 Genista legionensis samples (Table 2). The number of bands and the percentage of polymorphic bands produced by each primer varied (Table 2 ). A summary of the genetic diversity for each of the three populations of $G$. legionensis, based on AFLP markers, is given in Table 3. Low levels of genetic diversity were found in peripheral populations: the percentage of polymorphic bands ranged from $36.89 \%$ (GA) to $42.07 \%$ (ML), the mean observed number of alleles per locus

Table 3. Genetic diversity in populations of Genista legionensis based on AFLP markers.

\begin{tabular}{|c|c|c|c|c|c|c|c|c|c|}
\hline \multirow[b]{2}{*}{ Level } & \multicolumn{9}{|c|}{ AFLP } \\
\hline & PPB & $A_{o} \pm \mathrm{SE}$ & $A_{E} \pm \mathrm{SE}$ & $H_{\mathrm{E}} \pm \mathrm{SE}$ & $I \pm S E$ & $A_{P}$ & $A_{D}$ & $\boldsymbol{G}_{\mathrm{ST}}$ & $\mathrm{Nm}$ \\
\hline $\begin{array}{l}\text { Populations } \\
\text { GA } \\
\text { CA } \\
\text { ML } \\
\text { Average }\end{array}$ & $\begin{array}{l}36.89 \\
75.44 \\
42.07 \\
51.46 \\
\end{array}$ & $\begin{array}{c}1.368 \pm 0.482 \\
1.754 \pm 0.430 \\
1.420 \pm 0.493 \\
1.514 \\
\end{array}$ & $\begin{array}{c}1.181 \pm 0.308 \\
1.383 \pm 0.357 \\
1.211 \pm 0.326 \\
1.258\end{array}$ & $\begin{array}{c}0.109 \pm 0.171 \\
0.229 \pm 0.186 \\
0.126 \pm 0.180 \\
0.154\end{array}$ & $\begin{array}{c}0.167 \pm 0.249 \\
0.351 \pm 0.259 \\
0.192 \pm 0.261 \\
0.236\end{array}$ & $\begin{array}{c}36 \\
139 \\
33\end{array}$ & $\begin{array}{l}6 \\
0 \\
1\end{array}$ & & \\
\hline Species & 89.21 & $1.892 \pm 0.310$ & $1.414 \pm 0.365$ & $0.246 \pm 0.185$ & $0.377 \pm 0.249$ & & & 0.3922 & 0.3874 \\
\hline
\end{tabular}

PPB, percentage of polymorphic bands; $A_{o}$, observed mean number of alleles per locus; $A_{\varepsilon_{1}}$ effective mean of alleles per locus; $H_{\mathrm{E}}$, expected heterozygosity; $I$, Shannon diversity index; $A_{p}$, number of private alleles; $A_{D}$, number of discriminating alleles; $G_{s t}$, coefficient of genetic differentiation among populations; $N m$, gene flow. 
Table 4. Analysis of molecular variance (AMOVA) for the central and peripheral populations of Genista legionensis based on AFLP markers (d.f., degrees of freedom; SS, sums of squares; MS, mean sums of squares; VC, variance components). Level of significance are based on 9999 iteration steps.

\begin{tabular}{|c|c|c|c|c|c|c|}
\hline \multirow[b]{2}{*}{ Source of variation } & \multicolumn{6}{|c|}{ AFLP } \\
\hline & d.f. & SS & MS & VC & $\%$ & $\mathbf{p}$ \\
\hline Among populations & 2 & 2491.542 & 1245.771 & 74.246 & 52.11 & $<0.001$ \\
\hline Within populations & 47 & 3206.458 & 68.223 & 68.223 & 47.89 & $<0.001$ \\
\hline Total & 49 & 5698.000 & & 142.469 & & \\
\hline
\end{tabular}

ranged from 1.368 (GA) to 1.420 (ML) while the mean effective number of alleles per locus ranged from 1.181 (GA) to 1.211 (ML). The Nei's gene diversity ranged from 0.109 (GA) to 0.126 (ML), and the Shannon's information index ranged from 0.167 (GA) to $0.192(\mathrm{ML})$. In the case of the central population (CA), the percentage of polymorphic loci was higher $(75.44 \%)$. The mean observed number of alleles per locus was 1.754; while the mean effective number of alleles reached 1.383. The Nei's gene diversity and the Shannon's index were 0.229 and 0.351 , respectively. At species level, high levels of genetic diversity were revealed $\left(\mathrm{PPB}=89.21 \%, H_{\mathrm{E}}=\right.$ 0.246 and $I=0.377$ ). The estimated number of migrants per generation $(\mathrm{Nm})$ was 0.3874 (Table 3), which suggested a low rate of gene flow among populations. It is also noteworthy the presence of 208 private fragments in the three populations sampled ( 36 for GA, 139 for CA, 33 for ML), as well as the existence of 1 and 6 discriminating fragments in the populations of Monte Lucero (ML) and Gamoniteiro (GA), respectively.

The two-level AMOVA analysis from the distance matrices for the individuals studied (Table 4) showed that the percent of genetic variance explained by differences between groups detected by AFLP was $52.11 \%(\mathrm{P}<0.001)$, whereas the amount of variation within populations was $47.89 \%$ $(\mathrm{P}<0.001)$. In the principal coordinate analysis $(\mathrm{PCoA})$ the first three axes explained $43.62,14.30$ and $5.21 \%$ of the total variation respectively, and revealed three groups (Fig. 2). In accordance with the PCoA analysis, the NeighborNet (Fig. 3)

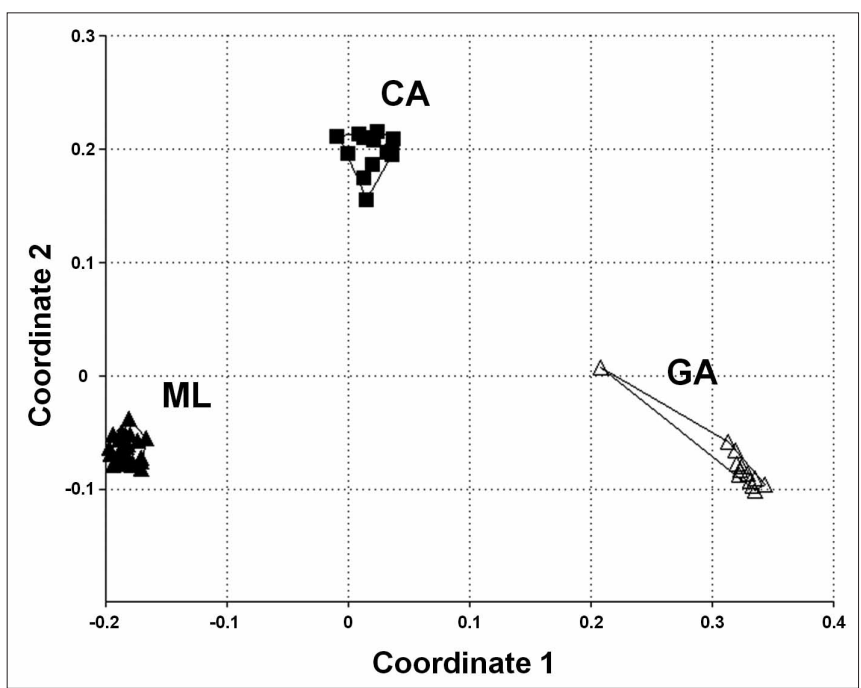

Fig. 2. Principal Coordinates Analysis ( $P C O A$ ) from Genista legionensis populations based on the correlation matrix of presence/absence of AFLP data: $\mathrm{CA}$, filled square $(\mathbf{\square})$; $\mathrm{GA}$, open triangle $(\Delta)$; $\mathrm{ML}$, filled triangle $(\boldsymbol{\Delta})$ illustrates three major splits corresponding also to the populations studied.

\section{DISCUSSION}

The genetic diversity of a population is usually related to the degree of isolation. Low levels of genetic diversity can be expected in peripheral populations as a result of low levels of immigration and high levels of genetic drift (e.g. Lesica \& Allendorf, 1995; García-Ramos \& Kirkpatrick, 1997). Our results support this scenario since the two peripheral populations of Genista legionensis exhibited lower genetic diversity than the central population. Declining genetic diversity towards the periphery of the species ranges has been found in many European/American species, such as: Alnus glutinosa (King \& Ferris, 1998), Arabidopsis thaliana (Kuittinen \& al., 1997), Calluna vulgaris (Mahy \& al., 1997), Stipa spp. (Wagner \& al., 2012; Durka \& al., 2013) or Thuja occidentalis (Pandey \& Rajora, 2012). Several mechanisms at peripheral populations may have led to the lower genetic diversity observed, such as genetic drift, that can provoke clines of genetic variation due to reduction of both habitat quality and quantity toward the periphery; or spatial isolation, with a lack of gene exchange between periphery populations (Eckert \& al., 2008).

The extremely low levels of genetic variation within peripheral populations of $G$. legionensis in the Cantabrian Range involve important implications for the conservation of this species. One of the major goals of conservation biology is to preserve the evolutionary potential of species (Höglund, 2009). In order to assess if a differentiation process is ongoing, as the adaptation of peripheral populations to different environments often reflects a stepping stone to speciation (Mayr, 1970), more detailed studies such as genome scan based on AFLP could be proposed (e.g. Paris \& Despres, 2012; Wang \& al., 2012). An increased sampling population would be needed, and by this data acquisition, more information would assist on determining the plausible scenarios: i) peripheral populations are under strong directional selection; ii) peripheral populations are at higher risk of genetic drift than central populations, and iii) habitats of the peripheral populations are often marginal near the species border and selection is severe, thus only a small number of genotypes survive (Lesica \& Allendorf, 1995).

Therefore, the interest of the peripheral populations of $G$. legionensis for conservation purposes would then mainly rely on their genetic uniqueness, and priority should be given to the preservation of these genetic pools. The loss of peripheral populations may decrease the species ability to adapt to future environment changes, and then reduce its potential for speciation (Channell, 2004). In conclusion, and according to 


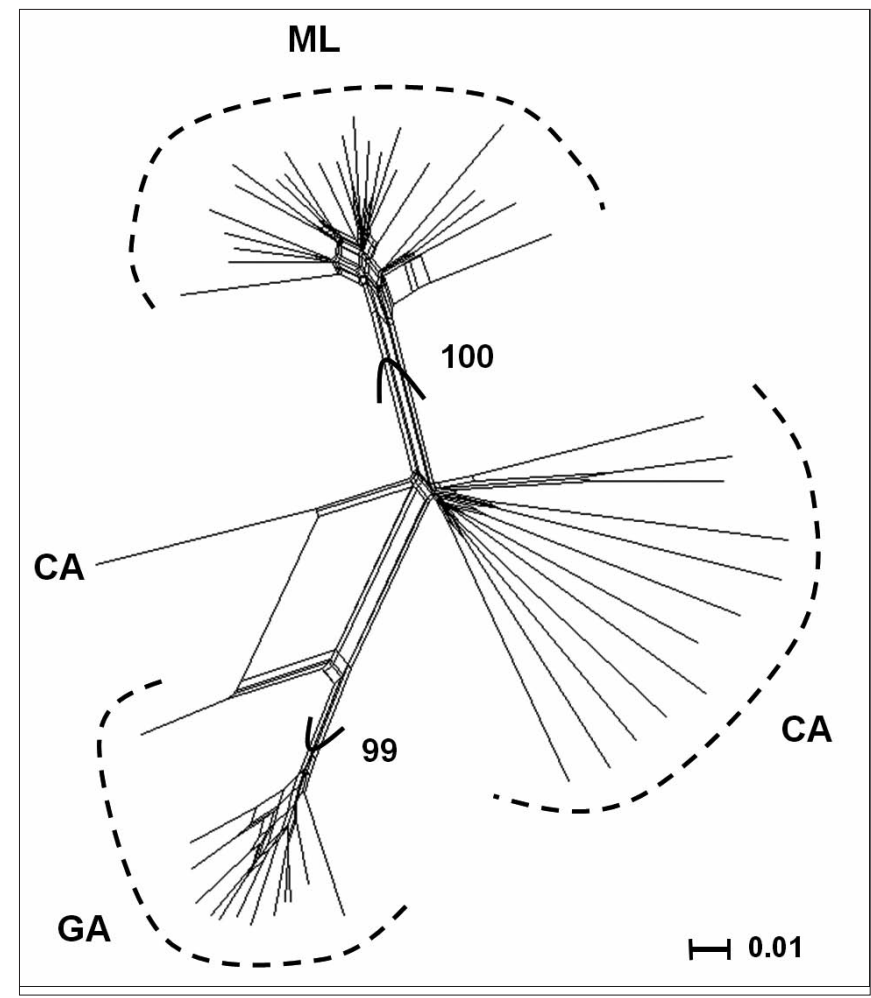

Fig. 3. NeighborNet derived from AFLP data of Genista legionensis. Numbers along branches are bootstrap values from neighbor-joining analysis $(2,000$ replicates). The least squares fit index for the split network has a value of $97.01 \%$. CA, Cabrales; GA, Gamoniteiro; ML, Monte Lucero.

the results presented, genetic monitoring should be kept, as long as fragmentation can have an effect on genetic variation in the long term, and we recommend the conservation of peripheral populations of Genista legionensis (i.e. Monte Lucero and Gamoniteiro), without meaning a global protection for the species in the Cantabrian Range as this endemic species is common in its distribution area.

\section{ACKNOWLEDGEMENTS}

We are grateful to A. Prieto for helping with the sampling. Special thanks to C. Cuesta and M. Herrera for critical reading and valuable comments throughout the manuscript. This research was funded by the Diputación Foral de Bizkaia (CN-10-061, Gobierno Vasco).

\section{REFERENCES}

Bañares, A., Blanca, G., Güemes, J., Moreno, J.C., \& Ortiz, S. (eds.). 2004. Atlas y libro rojo de la Flora Vascular Amenazada de España. Dirección General de la Conservación de la Naturaleza. Madrid.

Barreno, E., Bramwell, D., Cabezudo, B., Cardona, M.A., Costa, M., Fernández Casas, J., Fernández-Galiano, E., Fernández Prieto, J.A., Gómez Campo, C., Hernández Bermejo, E., Heywood, V.H., Izco, J., Llorens, L., Molero Mesa, J., Montserrat, P., Rivas Martínez, S., Sáenz Laín, C., Santos Guerra, A., Valdés, B. \& Wildpret, W. 1985. Listado de plantas endémicas, raras o amenazadas de España. Información Ambiental 3: 48-71.

B.O.P.V. 1998. Boletín Oficial del País Vasco, martes 28 de julio de 1998, $\mathrm{N}^{\circ}$ 141. Departamento de Industria, Agricultura y Pesca. N 3471 . Orden de 10 de julio de 1998, del Consejero de Industria, Agricultura y Pesca por la que se incluyen en el Catálogo Vasco de Especies Amenazadas de la Fauna y Flora, Silvestre y Marina, 130 taxones y 6 poblaciones de la flora vascular del País Vasco.
Channell, R. 2004. The conservation value of peripheral populations: the supporting science. In: Hooper, T.D. (ed.). Proceedings of the species at risk 2004: pathways to recovery conference. Victoria, BC.

Cires, E., Samain, M.-S., Goetghebeur, P. \& Fernández Prieto, J.A. 2011. Genetic structure in peripheral Western European populations of the endangered species Cochlearia pyrenaica (Brassicaceae). Plant Systematics and Evolution 297: 75-85.

De Castro, O., Cozzolino, S., Jury, S.L. \& Caputo, P. 2002. Molecular relationships in Genista L. Sect. Spartocarpus Spach (Fabaceae). Plant Systematics and Evolution 231: 91-108.

Durka, W., Nossol, C., Welk, E., Ruprecht, E., Wagner, V., Wesche, K. \& Hensen, I. 2013. Extreme genetic depauperation and differentiation of both populations and species in Eurasian feather grasses (Stipa). Plant Systematics and Evolution 299: 259-269.

Eckert, C.G., Samis, K.E. \& Lougheed, S.C. 2008. Genetic variation across species' geographical ranges: the central-marginal hypothesis and beyond. Molecular Ecology 17: 1170-1188.

Fernández Prieto, J.A., Díaz González, T.E. \& Nava Fernández, H.S. 2007. La protección de la flora vascular del Principado de Asturias. Naturalia Cantabricae 3: 37-56.

García-Ramos, G. \& Kirkpatrick, M. 1997. Genetic models of adaptation and gene flow in peripheral populations. Evolution 51:21-28.

Gibbs, P. E. 1966. Revision of the genus Genista L. Notes from the Royal Botanic Garden, Edinburgh 27: 11-99.

Gómez-Campo, C. 1987. Libro rojo de especies vegetales amenazadas de España Peninsular e Islas Baleares. Serie Técnica, ICONA. Madrid.

Hammer, Ø., Harper, D.A.T. \& Ryan, P.D. 2001. PAST: paleontological statistics software package for education and data analysis. Palaeontologia Electronica 4(1): 1-9.

Höglund, J. 2009. Evolutionary conservation genetics. Oxford University Press. Oxford.

Huson, D.H. \& Bryant, D. 2006. Application of phylogenetic networks in evolutionary studies. Molecular Biology and Evolution 23: 254-267.

King, R.A. \& Ferris, C. 1998. Chloroplast DNA phylogeography of. Alnus glutinosa (L.) Gaertn. Molecular Ecology 7: 1151-1161.

Kuittinen, H., Mattila, A. \& Savolaninen, O. 1997. Genetic variation at marker loci and in quantitative traits in natural populations of Arabidopsis thaliana. Heredity 79: 144-152.

Lawton, J.H. 1993. Range, population abundance and conservation. Trends in Ecology and Evolution 8: 409-413.

Lesica, P. \& Allendorf, F.W. 1992. Are small populations of plants worth preserving? Conservation Biology 6(1): 135-139.

Lesica, P. \& Allendorf, F.W. 1995. When are peripheral populations valuable for conservation? Conservation Biology 9(4): 753-760.

LLamas, F., Acedo, C., Lence, C., Alonso, R., Molina, A. \& Castro, V. 2007. Flora cantábrica de interés en Castilla y León. Naturalia Cantabricae 3: 57 78.

Mahy, G., Vekemans, X., Jacquemart, A.L. \& de Sloover, J.R. 1997. Allozyme diversity and genetic structure in south-western populations of heather, Calluna vulgaris (L.) Hull. New Phytologist 137: 325-334.

Mayr, E. 1970. Populations, species, and evolution. Harvard University Press. Massachusetts.

Moreno, J.C. (coord.). 2008. Lista roja 2008 de la flora vascular española. Madrid, Dirección General de Medio Natural y Política Forestal (Ministerio de Medio Ambiente, y Medio Rural y Marino, y Sociedad Española de Biología de la Conservación de Plantas).

Pandey, M. \& Rajora, O.P. 2012. Genetic diversity and differentiation of core vs. peripheral populations of eastern white cedar, Thuja occidentalis $(\mathrm{Cu}-$ pressaceae). American Journal of Botany 99(4): 690-699.

Pardo, C., Cubas, P. \& Tahiri, H. 2004. Molecular phylogeny and systematics of Genista (Leguminosae) and related genera based on nucleotide sequences of nrDNA (ITS region) and cpDNA ( $\operatorname{trn} \mathrm{L}-\operatorname{trn} \mathrm{F}$ intergenic spacer). Plant Systematics and Evolution 244: 93-119.

Paris, M. \&Despres, L. 2012. Identifying insecticide resistance genes in mosquito by combining AFLP genome scans and 454 pyrosequencing. Molecular Ecology 21: 1672-1686.

Peakall, R. \& Smouse, P.E. 2006. GENALEX 6: genetic analysis in Excel. Population genetic software for teaching and research. Molecular Ecology Notes 6: 288-295.

Talavera, S. 1999. Genista L. In: Talavera, S., Aedo, C., Castroviejo, S. Romero-Zarco, C., Sáez, L., Salgueiro, F.J. \& Velayos, M. (eds.). Flora 
iberica. Plantas vasculares de la Península ibérica e Islas Baleares VII(I), pp. 45-119. Real Jardín Botánico, CSIC. Madrid.

Vera de la Puente, M.L., Nava Fernández, H.S. \& Fernández Casado, M.A. 2002. Mapa 0758 - Genista legionensis (Pau) Laínz. Cavanillesia Altera 2 $142-150$

Vos, P., Hogers, R., Bleeker, M., Reijand, M., van de Lee, T., Hornes, M., Frijers, A., Pot, J., Peleman, J., Kuiper, M. \& Zabeau, M. 1995. AFLP: a new technique for DNA fingerprinting. Nucleic Acids Research 23: 4407-4414.

VV.AA. 2000. Lista roja de la flora vascular española (valoración según categorías UICN). Conservación Vegetal 6(extra): 1-39.

Wagner, V., Treiber, J., Danihelka, J., Ruprecht, E., Wesche, K. \& Hensen, I.
2012. Declining genetic diversity and increasing genetic isolation towards the range periphery of Stipa pennata, a Eurasian feather grass. International Journal of Plant Sciences 173(7): 802-811.

Wang, T., Chen, G., Zan, Q., Wang, C. \& Su, Y.-J. 2012. AFLP genome scan to detect genetic structure and candidate loci under selection for local adaptation of the invasive weed Mikania micrantha. PLoS ONE 7(7): e41310.

Associate Editor: Javier Fuertes Received: 16-II-2012

Accepted: 26-V-2013 